\title{
Using guanxi to conduct elite interviews in China
}

Qualitative Research 202I, Vol. 0(0) I-2I (C) The Author(s) 2021

\section{(c) (1)}

Article reuse guidelines: sagepub.com/journals-permissions DOI: $10.1|77 /| 468794|2| 1063486$ journals.sagepub.com/home/qrj

@SAGE

'Aston Business School, Birmingham, UK

${ }^{2}$ University of Exeter Business School, Exeter, Ireland

${ }^{3}$ University of Bristol Department of Management, Bristol, Ireland

\begin{abstract}
Drawing on two research projects in China, this article provides three contributions to the literature on elite interviews. First, we demonstrate how guanxi (informal, particularistic and personal connections) can help gain access and build trust with elite Chinese interviewees in a dynamic rather than a static manner. Second, we show the relational and ongoing process of elite interviewing, combining the sensemaking and sensegiving efforts of the interviewer and interviewee. We introduce the concept of sense-becoming to describe how researchers can develop a sense of strategy for future interviews. Third, we highlight the value of guanxi and co-positionality for the interviewer and interviewee to enhance interaction during interviews. We conclude by providing a heuristic for conceptualising the salience of guanxi and sensemaking for elite interviews in China.
\end{abstract}

\section{Keywords}

Guanxi, elite leaders, interviewing, sensemaking, sensegiving

\section{Introduction}

Given the imbalance of power relations and asymmetry of knowledge between interviewers and interviewees (McDowell, 1998), elite interviews represent unique methodological challenges compared to non-elite interviews (Mikecz, 2012), particularly for

\section{Corresponding author:}

William S Harvey, School of Management, Faculty of Social Sciences and Law, University of Bristol, Howard House, Queen's Avenue, Bristol, BS8 ISD, Ireland.

Email: will.harvey@bristol.ac.uk 
those new to researching this group. Social scientists have paid much attention to interviewing elites, including gaining access and building trust, which are critical for collecting high quality data (Empson, 2017; Harvey, 2011, 2021). Other scholars have argued that some subtle threats have been ignored such as engendering interest among different groups of interviewees (Ostrander, 1993; Smigel, 1958). Despite the proliferation of sensemaking-related research (Gioia and Chittipeddi, 1991; Sonenshein, 2010), it is surprising that this body of literature has not been applied in the context of elite interviewing where it could play a powerful role because researchers need to constantly craft and re-craft a sense of how to improve. This is particularly true when we are conducting fieldwork in unfamiliar contexts.

China is an increasingly important research context for understanding elites, particularly given its growing influence in global politics and business (Cunningham and Rowley, 2008). Chinese culture has a higher power-distance orientation (Hofstede, 2011), where power is distributed unequally. This invites us to understand the effects of the political sensitivities of different authorities when considering fieldwork prospects in China (Lu, 2012). Despite having a strong resonance with elite interviews in the West, the Chinese context is characterised by cultural differences in values, beliefs, communications and norms (Mikecz, 2012). As a widespread practice in China, guanxi has drawn growing attention (Farh et al., 1998; Yang, 2001), but remains under-examined in research methods. This is a shortcoming given that the relationship between the interviewer and interviewee is essential, which raises the question of how guanxi can be beneficial in Chinese elite interviewing in China.

This article draws on the first author's reflections from 42 elite Chinese interviews undertaken in China. Predicated on understanding the interview as a process (England, 1994), we provide interviewing guidelines and explain how researchers can be in tune with the dynamic and relational interviewing process between the interviewer and interviewee in a specific Chinese guanxi context. From this, researchers new to conducting elite interviews in China will understand how to evolve a sense of employing guanxi to conduct these kinds of interviews more effectively, which is a process that we term 'sense-becoming'.

\section{Challenges and strategies for elite interviewing}

Guanxi and elite interviewing. It has been argued that it can be more challenging, timeconsuming and costly to gain access to elite leaders (Mikecz, 2012). We refer to elites as the figureheads or leaders in China who hold hierarchical positions, influence decisionmaking in organisations and who hold significant political power (Mavin et al., 2014). The collection of high-quality data relies on trust, which is essential to open up the 'the inner world (meanings, ideas, feelings and intentions)' of the interviewee (Alvesson, 2003:16). Researchers have little bargaining power in negotiating research access (Cooke, 2002: p.23) because potential interviewees, particularly in cases of small and mediumsized enterprises (SMEs), are suspicious and reluctant to participate in academic research in China (Heneman et al., 2000).

As a Chinese indigenous construct, guanxi refers to 'an informal, particularistic personal connection between two individuals' to maintain 'mutual commitment, loyalty 
and obligation' (Chen and Chen, 2004:306). Guanxi building tends to be initiated after identifying guanxi bases which is arguably distinctive in Chinese culture in three types (Jacobs, 1980): preordained family ties (kinship), familiar persons (e.g. former classmates) and strangers. We focus on the second guanxi base, which means two parties who share commonalities (tong), such as those originally from a common birthplace (tongxiang) or who have worked in the same organisation (tongshi). Given the guanxi base describes the foundation of the relationship, it is suggestive of a static being. However, it can be enhanced through personal interaction, which links to guanxi quality, referring to the subjective perceptions of the level of guanxi (Chen and Chen, 2004). Trust (xing) is vital for building up positive guanxi - the higher level of trust, the better guanxi quality. We recognise that certain negative types of guanxi may be related to corruption, bribery and unethical conduct in Chinese business practices (Dunfee and Warren, 2001). Our focus is on the potential positive aspects of guanxi for facilitating fieldwork. Trust is constitutive of sincerity and ability: the former means one's true intention related to reliability (Yang, 2001), while the latter weighs towards one's specific competence or expertise in certain areas (McAllister, 1995). While guanxi is advantageous in gaining access and building trust, the mechanism of guanxi and guanxi quality remains underexplored and an essential rationale for illustrating the agency of guanxi for conducting elite interviews.

\section{Positionality}

Harvey (2011) delineates guidelines and challenges for conducting elite interviews such as trust-building, dealing with challenging scenarios and engaging with interviewees. His motivation was to help early career researchers (ECRs) to 'avoid some of these pitfalls' in interviewing elites, for example, to 'gauge early the atmosphere of the interview and adjust their behaviour, speaking voice and mannerisms accordingly' (Harvey, 2011:431434). This is significant as such considerations can present significant problems between the interviewer and the interviewee if power dynamics are not managed with skill and subtlety (Empson, 2017).

Elite interviewees can challenge an interviewer's knowledge surrounding a topic (Zuckerman, 1972) and patronise the interviewer. In view of this, there has been a repeated reminder of doing your homework (Empson, 2017) to increase knowledge about the portfolio of elites and the research context. Demonstration of sufficient knowledge is significant as it could reduce the imbalance of knowledge and power (McDowell, 1998), inform an interview protocol (Jacob and Furgerson, 2012) and enhance the quality of interviewing (Welch et al., 2002). However, neither training nor methodological books can fully prepare the researcher for elite or any kind of interviewing (Kezar, 2003).

An appropriate positionality of the interviewer is central for any interviews (Harvey, 2021; Mikecz, 2012) and a researcher's positionality may influence data collection, which links to one's social identity such as race, social and economic status (Madge, 1993), however, interviewing is essentially a relational and social interaction process (Lee and Aslam, 2018). For example, McDowell (1998:2138) draws on the observations of interviewees, and skilfully describes shifting her role, ranging from 'playing dumb' with 
senior patriarchal figures to being 'sisterly' with women of a similar age. The particularities and idiosyncrasies of individual elites call for the wisdom of the moment (Case and Gosling, 2007) as the researcher needs to be in tune with the situated scenarios, reflect on the relational dynamics, continuously craft the plausible sense of the context and re-craft their subsequent efforts, which surfaces sensemaking efforts.

\section{Sensemaking and sensegiving}

The researcher needs to engage in the ongoing sensemaking process, which means how people 'work to understand novel, unexpected or confusing events' (Maitlis and Christianson, 2014:58). Since the foundational work of Weick's (1995) Sensemaking in Organizations, extensive literature on sensemaking has been well-documented. While the prompts of sensemaking are largely agreed upon, scholars recognise questions around how it is accomplished and shared (Maitlis and Christianson, 2014). One key ontological difference lies in whether sensemaking occurs within individuals as a more cognitive process (Elsbach et al., 2005) or between people as an inherently social and discursive process (Weick, 1995; Weick et al., 2005). From a cognitive perspective, sensemaking focuses on appraisal and interpretation to develop frameworks or mental models through distinct aspects such as comprehending and predicting (Starbuck and Milliken, 1988). In contrast, Weick (1995, p.409) sees 'social' as one of the seven dimensions of sensemaking that unfolds 'in a social context of other actors', where meaning is continuously negotiated and co-constructed. As interviewing is essentially a relational and social interaction process (Lee and Aslam, 2018), we agree with scholars who stress the collective nature of sensemaking and focus on the social dynamics related to elite interviewing.

Sensemaking is incomplete without its variant of sensegiving that refers to the "process of attempting to influence the sensemaking and meaning construction of others towards a preferred redefinition of others' (Gioia and Chittipeddi, 1991:442). Sensegiving has often been examined about how leaders or managers strategically influence the sensemaking efforts of organisational members through the use of artefacts, images and other techniques (Gioia and Chittipeddi, 1991). Although it can be a top-down process, other parties can proactively engage in their own interpretations rather than passively shaped by leaders' efforts (Sonenshein, 2010).

Despite the well-documented sensemaking-related research in strategic change (Gioia and Chittipeddi, 1991), organisational learning (Haas, 2006) and leadership (Pye, 2005), it has been under-explored in elite interviewing. This is a significant oversight because sensemaking is potentially helpful to 'clarify what is going on by extracting and interpreting cues from the environment' (Maitlis and Christianson 2014:58) when researchers are confronted with ambiguity or uncertainty in elite interviewing.

\section{Making sense of elite interviewing in China}

This study draws upon the first author's experiences interviewing 42 elite leaders during a $\mathrm{PhD}$ and a post-doctoral research project, with the fieldwork conducted in 2013-2014 with SMEs and in 2016-2017 within a large financial services corporation in China. The 
composition of the interviewees is summarised in Table 1 . The $\mathrm{PhD}$ project examined how leaders explored and exploited knowledge to grow their businesses in the Shanghai logistics industry informed by Daoism. The first author was originally from an entrepreneurship family in the logistics sector in Shanghai; thus she possessed sufficient knowledge of this sector and familiarity with the leadership dynamic. The post-doc project was an in-depth case study exploring how CEOs strengthened identity and reputation in an elite financial services company. The first author had scant knowledge about the sector but had accumulated some elite interviewing experience based on her $\mathrm{PhD}$ project. The fieldwork for both projects was organised into three stages: exploring, engaging and reflecting, which we now elaborate on.

Exploring. Guanxi permeates almost every social interaction in China. Initially, the researcher needs to employ guanxi to connect with the gatekeeper for research access. Subsequently, an appropriate selection of the suitable medium of communication is vital for establishing and strengthening connections with interviewees. Lastly, before asking formal interview questions, an informal taster talk is helpful to break the ice and create rapport.

Guanxi matters. In the context of both sets of fieldwork in China, we found that guanxi was crucial to gain research access. Both the $\mathrm{PhD}$ project and post-doc project were mobilised by guanxi. The $\mathrm{PhD}$ project was introduced by the first author's partner, who had strong guanxi with a vital gatekeeper, the vice-chairman of a significant industry committee, which is an influential political and professional body in the field. The vicechairman went the extra mile to provide the committee members' contacts and encourage them to support the research. However, he had no direct control over the participants, which would have contravened the research project's ethical code of conduct. Hence, participants demonstrated varying levels of buy-in during the process of interviewing. The post-doc project was introduced by the CEO's family member, who was the first author's long-term friend and colleague at a prestigious university in the UK. This strong guanxi not only enabled good support from the CEO but also his trust and respect. When the first author met with him, he articulated:

As a financial services company, we are always swamped and most staff need to work overtime. If my family member did not introduce you, I would certainly not support your research at all. To give him face (mianzi), I am happy to support you fully. You can interview whoever you like at my company. (Interviewee 5)

Indeed, the CEO made various efforts to support the study:

I first sent an email to the management team, introducing the details of your project and asking them to support your research. I then sent out another email to all the employees, asking them to support your interviews. Otherwise, I don't think they would be engaged. (Interviewee 5) 
Table I. List of elite interviewees.

\begin{tabular}{|c|c|c|c|c|c|c|c|}
\hline $\begin{array}{l}\text { Interviewee } \\
\text { \# }\end{array}$ & Title & Gender & Education & Nationality & $\begin{array}{l}\text { Type } \\
\text { of } \\
\text { Firm }\end{array}$ & Industry & $\begin{array}{l}\text { Type of } \\
\text { Interview }\end{array}$ \\
\hline I & $\begin{array}{l}\text { Board } \\
\text { Chairman }\end{array}$ & Male & Master & Chinese & Elite & $\begin{array}{l}\text { Financial } \\
\text { services }\end{array}$ & $\begin{array}{l}\text { Face-to- } \\
\text { face }\end{array}$ \\
\hline 2 & $\begin{array}{l}\text { Board } \\
\text { Director }\end{array}$ & Male & Master & Chinese & Elite & $\begin{array}{l}\text { Financial } \\
\text { services }\end{array}$ & $\begin{array}{l}\text { Face-to- } \\
\text { face }\end{array}$ \\
\hline 3 & $\begin{array}{l}\text { Board } \\
\text { Director }\end{array}$ & Male & Bachelor & Chinese & Elite & $\begin{array}{l}\text { Financial } \\
\text { services }\end{array}$ & Telephone \\
\hline 4 & $\begin{array}{l}\text { Board } \\
\text { Director }\end{array}$ & Male & Master & Chinese & Elite & $\begin{array}{l}\text { Financial } \\
\text { services }\end{array}$ & Telephone \\
\hline 5 & CEO & Male & Doctor & Chinese & Elite & $\begin{array}{l}\text { Financial } \\
\text { services }\end{array}$ & $\begin{array}{l}\text { Face-to- } \\
\text { face }\end{array}$ \\
\hline 6 & $\begin{array}{l}\text { Deputy } \\
\text { General } \\
\text { Manager }\end{array}$ & Male & Master & Chinese & Elite & $\begin{array}{l}\text { Financial } \\
\text { services }\end{array}$ & $\begin{array}{l}\text { Face-to- } \\
\text { face }\end{array}$ \\
\hline 7 & $\begin{array}{l}\text { Deputy } \\
\text { General } \\
\text { Manager }\end{array}$ & Male & Doctor & Chinese & Elite & $\begin{array}{l}\text { Financial } \\
\text { services }\end{array}$ & $\begin{array}{l}\text { Face-to- } \\
\text { face }\end{array}$ \\
\hline 8 & $\begin{array}{l}\text { Deputy } \\
\text { General } \\
\text { Manager }\end{array}$ & Male & Master & Chinese & Elite & $\begin{array}{l}\text { Financial } \\
\text { services }\end{array}$ & $\begin{array}{l}\text { Face-to- } \\
\text { face }\end{array}$ \\
\hline 9 & $\begin{array}{l}\text { Deputy } \\
\text { General } \\
\text { Manager }\end{array}$ & Female & Master & Chinese & Elite & $\begin{array}{l}\text { Financial } \\
\text { services }\end{array}$ & $\begin{array}{l}\text { Face-to- } \\
\text { face }\end{array}$ \\
\hline 10 & Director & Female & Master & Chinese & Elite & $\begin{array}{l}\text { Financial } \\
\text { services }\end{array}$ & $\begin{array}{c}\text { Face-to- } \\
\text { face }\end{array}$ \\
\hline II & Director & Female & Master & Chinese & Elite & $\begin{array}{l}\text { Financial } \\
\text { services }\end{array}$ & $\begin{array}{l}\text { Face-to- } \\
\text { face }\end{array}$ \\
\hline 12 & Director & Female & College & Chinese & Elite & $\begin{array}{l}\text { Financial } \\
\text { services }\end{array}$ & $\begin{array}{l}\text { Face-to- } \\
\text { face }\end{array}$ \\
\hline 13 & Director & Male & Master & Chinese & Elite & $\begin{array}{l}\text { Financial } \\
\text { services }\end{array}$ & $\begin{array}{l}\text { Face-to- } \\
\text { face }\end{array}$ \\
\hline 14 & Director & Male & Master & Chinese & Elite & $\begin{array}{l}\text { Financial } \\
\text { services }\end{array}$ & $\begin{array}{l}\text { Face-to- } \\
\text { face }\end{array}$ \\
\hline 15 & Director & Male & Master & Chinese & Elite & $\begin{array}{l}\text { Financial } \\
\text { services }\end{array}$ & $\begin{array}{l}\text { Face-to- } \\
\text { face }\end{array}$ \\
\hline 16 & Director & Male & Master & Chinese & Elite & $\begin{array}{l}\text { Financial } \\
\text { services }\end{array}$ & $\begin{array}{l}\text { Face-to- } \\
\text { face }\end{array}$ \\
\hline 17 & Director & Female & Master & Chinese & Elite & $\begin{array}{l}\text { Financial } \\
\text { services }\end{array}$ & $\begin{array}{c}\text { Face-to- } \\
\text { face }\end{array}$ \\
\hline 18 & Director & Male & Master & Chinese & Elite & $\begin{array}{l}\text { Financial } \\
\text { services }\end{array}$ & $\begin{array}{l}\text { Face-to- } \\
\text { face }\end{array}$ \\
\hline
\end{tabular}


Table I. (continued)

\begin{tabular}{|c|c|c|c|c|c|c|c|}
\hline $\begin{array}{l}\text { Interviewee } \\
\#\end{array}$ & Title & Gender & Education & Nationality & $\begin{array}{l}\text { Type } \\
\text { of } \\
\text { Firm }\end{array}$ & Industry & $\begin{array}{l}\text { Type of } \\
\text { Interview }\end{array}$ \\
\hline 19 & Director & Female & Master & Chinese & Elite & $\begin{array}{l}\text { Financial } \\
\text { services }\end{array}$ & $\begin{array}{l}\text { Face-to- } \\
\text { face }\end{array}$ \\
\hline 20 & Director & Female & Master & Chinese & Elite & $\begin{array}{l}\text { Financial } \\
\text { services }\end{array}$ & $\begin{array}{l}\text { Face-to- } \\
\text { face }\end{array}$ \\
\hline 21 & Director & Male & Master & Chinese & Elite & $\begin{array}{l}\text { Financial } \\
\text { services }\end{array}$ & $\begin{array}{l}\text { Face-to- } \\
\text { face }\end{array}$ \\
\hline 22 & Director & Male & Master & Chinese & Elite & $\begin{array}{l}\text { Financial } \\
\text { services }\end{array}$ & $\begin{array}{l}\text { Face-to- } \\
\text { face }\end{array}$ \\
\hline 23 & Director & Male & Master & Chinese & Elite & $\begin{array}{l}\text { Financial } \\
\text { services }\end{array}$ & $\begin{array}{l}\text { Face-to- } \\
\text { face }\end{array}$ \\
\hline 24 & Director & Female & Master & Chinese & Elite & $\begin{array}{l}\text { Financial } \\
\text { services }\end{array}$ & $\begin{array}{l}\text { Face-to- } \\
\text { face }\end{array}$ \\
\hline 25 & Director & Female & Bachelor & Chinese & Elite & $\begin{array}{l}\text { Financial } \\
\text { services }\end{array}$ & $\begin{array}{l}\text { Face-to- } \\
\text { face }\end{array}$ \\
\hline 26 & Director & Male & Master & Chinese & Elite & $\begin{array}{l}\text { Financial } \\
\text { services }\end{array}$ & $\begin{array}{l}\text { Face-to- } \\
\text { face }\end{array}$ \\
\hline 27 & Director & Male & Doctor & Chinese & Elite & $\begin{array}{l}\text { Financial } \\
\text { services }\end{array}$ & $\begin{array}{l}\text { Face-to- } \\
\text { face }\end{array}$ \\
\hline 28 & Director & Female & Master & Chinese & Elite & $\begin{array}{l}\text { Financial } \\
\text { services }\end{array}$ & $\begin{array}{l}\text { Face-to- } \\
\text { face }\end{array}$ \\
\hline 29 & Director & Male & Master & Chinese & Elite & $\begin{array}{l}\text { Financial } \\
\text { services }\end{array}$ & $\begin{array}{l}\text { Face-to- } \\
\text { face }\end{array}$ \\
\hline 30 & Director & Female & Master & Chinese & Elite & $\begin{array}{l}\text { Financial } \\
\text { services }\end{array}$ & $\begin{array}{l}\text { Face-to- } \\
\text { face }\end{array}$ \\
\hline 31 & $\begin{array}{l}\text { General } \\
\text { Manager }\end{array}$ & Male & $\begin{array}{l}\text { High } \\
\text { school }\end{array}$ & Chinese & Micro & $\begin{array}{l}\text { Logistics } \\
\text { services }\end{array}$ & $\begin{array}{l}\text { Face-to- } \\
\text { face }\end{array}$ \\
\hline 32 & $\begin{array}{l}\text { General } \\
\text { Manager }\end{array}$ & Male & $\begin{array}{c}\text { Below high } \\
\text { school }\end{array}$ & Chinese & Micro & $\begin{array}{l}\text { Logistics } \\
\text { services }\end{array}$ & $\begin{array}{l}\text { Face-to- } \\
\text { face }\end{array}$ \\
\hline 33 & $\begin{array}{l}\text { General } \\
\text { Manager }\end{array}$ & Male & $\begin{array}{l}\text { High } \\
\text { school }\end{array}$ & Chinese & Micro & $\begin{array}{l}\text { Logistics } \\
\text { services }\end{array}$ & $\begin{array}{l}\text { Face-to- } \\
\text { face }\end{array}$ \\
\hline 34 & $\begin{array}{l}\text { General } \\
\text { Manager }\end{array}$ & Female & $\begin{array}{l}\text { College } \\
\text { degree }\end{array}$ & Chinese & Micro & $\begin{array}{l}\text { Logistics } \\
\text { services }\end{array}$ & $\begin{array}{l}\text { Face-to- } \\
\text { face }\end{array}$ \\
\hline 35 & $\begin{array}{l}\text { General } \\
\text { Manager }\end{array}$ & Male & MBA & Chinese & Small & $\begin{array}{l}\text { Logistics } \\
\text { services }\end{array}$ & $\begin{array}{l}\text { Face-to- } \\
\text { face }\end{array}$ \\
\hline 36 & $\begin{array}{l}\text { General } \\
\text { Manager }\end{array}$ & Male & $\begin{array}{c}\text { Bachelor } \\
\text { degree }\end{array}$ & Chinese & Small & $\begin{array}{l}\text { Logistics } \\
\text { services }\end{array}$ & $\begin{array}{l}\text { Face-to- } \\
\text { face }\end{array}$ \\
\hline 37 & $\begin{array}{c}\text { Co- } \\
\text { Chairman }\end{array}$ & Male & $\begin{array}{c}\text { Bachelor } \\
\text { degree }\end{array}$ & Chinese & Small & $\begin{array}{l}\text { Logistics } \\
\text { services }\end{array}$ & $\begin{array}{l}\text { Face-to- } \\
\text { face }\end{array}$ \\
\hline 38 & $\begin{array}{c}\text { Chairman } \\
\text { \& General } \\
\text { Manager }\end{array}$ & Male & $\begin{array}{l}\text { College } \\
\text { degree }\end{array}$ & Chinese & Small & $\begin{array}{l}\text { Logistics } \\
\text { services }\end{array}$ & $\begin{array}{l}\text { Face-to- } \\
\text { face }\end{array}$ \\
\hline
\end{tabular}


Table I. (continued)

\begin{tabular}{|c|c|c|c|c|c|c|c|}
\hline $\begin{array}{l}\text { Interviewee } \\
\#\end{array}$ & Title & Gender & Education & Nationality & $\begin{array}{l}\text { Type } \\
\text { of } \\
\text { Firm }\end{array}$ & Industry & $\begin{array}{l}\text { Type of } \\
\text { Interview }\end{array}$ \\
\hline 39 & President & Male & MBA & Chinese & Medium & $\begin{array}{l}\text { Logistics } \\
\text { services }\end{array}$ & $\begin{array}{l}\text { Face-to- } \\
\text { face }\end{array}$ \\
\hline 40 & President & Male & $\begin{array}{c}\text { Bachelor } \\
\text { degree }\end{array}$ & Chinese & Medium & $\begin{array}{l}\text { Logistics } \\
\text { services }\end{array}$ & $\begin{array}{l}\text { Face-to- } \\
\text { face }\end{array}$ \\
\hline 41 & CEO & Male & $\begin{array}{c}\text { Below high } \\
\text { school }\end{array}$ & Chinese & Medium & $\begin{array}{l}\text { Logistics } \\
\text { services }\end{array}$ & $\begin{array}{l}\text { Face-to- } \\
\text { face }\end{array}$ \\
\hline 42 & CEO & Female & $\begin{array}{l}\text { Bachelor } \\
\text { degree }\end{array}$ & Chinese & Medium & $\begin{array}{l}\text { Logistics } \\
\text { services }\end{array}$ & $\begin{array}{l}\text { Face-to- } \\
\text { face }\end{array}$ \\
\hline
\end{tabular}

To better support the study, the CEO assigned a marketing member of staff to act as a temporary 'research assistant'. Based on a portfolio of interviewees and internal archives requested by the first author, the research assistant provided confidential documents such as Board meeting memos, scheduled all the relevant interviews and showed her around the office to conduct observations. We had autonomy regarding who we interviewed, what we asked them and the nature of our probing questions. This combination ensured that we could tease out a more comprehensive understanding of the organisational dynamics rather than having a skewed perspective of the organisation from the perspective of elites. The unique guanxi mobilised research access so that the first author could complete the $\mathrm{PhD}$ and post-doc projects, having collected rich data. Whenever possible, we suggest that it is helpful to have support from above. This can facilitate research access and buy-in from interviewees, though importantly, they did not and should not influence the process of the interviews.

\section{Selecting the suitable medium of communication}

In the PhD project, the vice-chairman of the major industry committee mentioned above offered the committee member list (with their permission) to the first author, including telephone numbers and e-mail addresses. Initially, the first author contacted them by telephone to introduce herself and the research, and confirm whether they would be willing to conduct a face-to-face interview. But, this was ineffective and an embarrassing experience as fraudulent or commercial advertisement telephone calls are frequent in China. Drawing on this experience, the first author abandoned the telephone approach and contacted interviewees by text message and e-mail, with text messages being more effective. Thanks to their guanxi with the vice chairman, most of them agreed to accept interviews and were more proactive in replying by text message.

When launching the post-doc project in 2016, the social media site, WeChat, became popular in China, proving instrumental in preparing and establishing guanxi for the research project. The first author was introduced to the CEO through WeChat, and prior to 
the fieldwork, she read the CEO's posts on his WeChat, which frequently spread Kazuo Inamori's philosophy:

Inamori identifies the Six Endeavours as essential in managing business and living an extraordinary life: diligence, humility, reflection, gratitude, benevolence and detachment. (from WeChat)

The CEO commented on this post: 'I think diligence is particularly important for anybody'. In so doing, the first author gained preliminary knowledge of the CEO's philosophy and leadership style and the ongoing status of his organisation, which complemented the information available on the company's website. Then the first author commenced initial contact by leaving him a greeting message through WeChat, which unlike a telephone call or standard text message, had the advantage of being more informative because of the additional ongoing information available. After being connected with the CEO on WeChat, the first author maintained regular communication for three months, leading to enhanced guanxi quality. Through this medium, both parties had 'seen' each other virtually, thus helping to remove potential barriers such as ice-breakers. The exploring stage also helped to strengthen guanxi and trusted relationships, such as a coughing incident that we will discuss later where the first author observed the CEO's belief in diligence.

\section{Taster talk}

Although it might appear too personal in Western contexts, it is a Chinese tradition to ask: 'Where are you originally from?' at their first meeting. This can open up an opportunity to create rapport and develop guanxi:

Interviewee 35: Where are you initially from? From your accent, I guess you might be from Jiangxi?

Interviewer: Oh, yes, I am originally from Jiangxi.

Interviewee 35: Really? Interesting! My wife is also originally from Jiangxi. You are tongxiang.

Chinese people value the guanxi base of tongxian (town fellowship), referring to people originally from a common birthplace. Since the interviewee's wife and the first author were tongxian, it immediately cultivated guanxi and reduced the otherwise distant stranger relationship. However, informal talk is not suitable or appropriate for all interviews. For example, one interviewee seemed to have a particularly tight schedule and suggested he could only confirm the interview time the night before the interview day. When the interview was finally confirmed, the first author was not surprised to see him having biscuits for lunch while entering his office at a late hour in the afternoon. It strongly signalled that he only had limited time for the interview such that it would be hard to accommodate a taster talk. 


\section{Engaging}

Mimicking. In the process of doing preparatory work prior to the $\mathrm{PhD}$ interviews, the first author realised that more than half of the interviewees had limited higher education qualifications. In light of this observation, she deliberately fine-tuned her positionality. For example, one interviewee (Interviewee 41) repeatedly stressed he was initially from a deprived area of the countryside and had only completed high school, which he demonstrated some embarrassment. Hence the first author tried not to talk about her $\mathrm{PhD}$ studies but sympathised:

What a coincidence! I was originally from an isolated countryside too. People from the countryside tend to be more hardworking than those growing up in big cities like Shanghai, don't we? (Interviewer)

In the above message, the first author purposefully used 'we' to project a strong sense of guanxi: this shared positionality (from the countryside) helped the interviewee to feel much more relaxed and became enthusiastic about narrating his leadership trajectory.

Given the post-doc project focused on an elite financial services company, the profiles of interviewees were starkly different, and almost all of them showed pride in their highlevel qualifications (e.g. MSc or PhD degrees from the University of Cambridge or Peking University). Hence, the first author switched to self-promotion to enhance credibility and reduce power imbalance. She provided a detailed introduction about herself and her $\mathrm{PhD}$ supervisor and highlighted the top ranking of their institutions before the interviews:

I have just completed my PhD at the University of Exeter Business School, which is Top 10 in the UK...I am doing this project in collaboration with my $\mathrm{PhD}$ supervisor, the associate dean. He completed his $\mathrm{PhD}$ at the University of Cambridge and post-doc at the University of Oxford...

The CEO disseminated the above introduction within his company, which contributed to positive impression management and helped to persuade many people to participate in the study. In the process of interviewing, she also reiterated the above message. Quite a few interviewees responded that they knew the Business School, as they also completed an MSc in the UK, which again helped with guanxi quality and convinced them to participate in the study.

Using visual artefacts as prompts. Chinese leaders tended to display visual artefacts such as drawings or calligraphic art in their office settings. The artefacts are often a means to project their philosophy, leadership style or organisational values, which can be employed as valuable prompts for interviewers to engage the interviewees. For example, one interviewee (Interviewee 39) appeared reluctant to talk in the PhD project, only providing brief answers such as 'yes' or 'no' to many of the questions. In the middle of the interview, he happened to leave his office. The first author took this as an opportunity to observe his 
office settings carefully and noticed a robust Daoist element on the office wall and desk calendar. On his return to the office, she enticed:

The drawing patterns on the wall and in the calendar are related to Daoism. Why do they look like that? (Interviewer)

Unexpectedly, he immediately became very engaged with a long narration:

I am originally from Suzhou. The Classical Gardens of Suzhou is strongly suggestive of Daoist philosophy. I grew up in this kind of Daoist culture... (Interviewee 39)

It was evident that the Daoist topic opened up what would otherwise have been a 'closed door' interview. In the case of another interview, the interviewee (Interviewee 33) was asked to reflect on his growth trajectory and strategies. The interviewee struggled to express his reflections, thus his answers were very brief. The first author noticed an ideographic character ying (to win) at his office, comprising 'five elements to win' such as openness to fail and recommendation by word-of-mouth. This visual artefact encapsulated the emphasis on growth strategies. The first author then used these five elements to improvise additional interview questions:

The ideographic character ying looks very interesting. The first element is openness to failure. How do you understand it? (Interviewer)

This technique was beneficial as the artefact provided a framework to organise his thoughts, which led to detailed and rich responses.

Embracing tea culture. China boasts a long history of tea culture. The first author was invited to enjoy tea at two interviews by the Board Chairman and CEO. The Board Chairman (Interviewee 1) happened to be late by 15 minutes and asked his secretary to show the first author to his office to wait for him. She took this opportunity to observe his exquisitely decorated office setting, suggestive of his bureaucratic position and power. Before the interview, the first author had done extensive homework such as reviewing a variety of his media coverage and Board meeting memos. She learned that his previous role was deputy head of a consultancy committee to the former Chinese President. She was concerned that such an 'ultra elite' with a senior government leadership background might appear aloof and hierarchical based on her Chinese cultural background. The magnificent office settings exacerbated her anxiety and challenged her confidence, though fortunately she had accumulated some experience from previous elite interviewing. However, the board Chairman was highly approachable and began by inviting her to sit down for tea. This episode was unexpected but made her relaxed:

Well, very nice tea! I guess it is Dragon Well tea? I like the aroma...it tastes mellow and rounded. I really like this tea. (Interviewer) 
The 'tea break' was productive as it cultivated a relaxing and informal environment for the first author to gain her composure. It also provided a moment for the Board Chairman to stop and reflect on his leadership given his hustle-and-bustle schedule. The interview lasted for 3 hours, in the course of which he purposefully paused to enjoy the tea twice. The tea intervals presented the first author with unique opportunities to reflect on her questions and his answers. He possessed a high level of communication skills, and his thought-provoking reflections invited her to pursue further questions beyond the scope of her preparation. This interview proved to be highly productive, and undoubtedly built-up rapport and strengthened guanxi, as the Board Chairman promised to recommend many other potential interviewees for her. Another interviewee (Interviewee 37) also invited the first author to enjoy quality tea in a spacious tea room. He even played light music and invited two project managers to join the interview, which was the only exception among all of the interviews. After exchanging business cards, he suggested:

Let's have tea first and listen to some music. Today it is pretty cool, isn't it? It is suitable for our health to drink some warm tea before it becomes cold. (Interviewee 37)

Throughout the 2-hour interview, the interviewee added some more hot tea and repeatedly reminded his project managers of drinking it before it cooled down. These details indicated that the interviewee stressed well-being and guanxi in this cultural context. Given this, the first author improvised her questions: 'How nice to be your employees you care about them so much! Do you do something particular to support them?' Indeed, the interviewee had some unique approaches. For example, he pursued the career development of exit staff and used it as a 'mirror'. If they developed better in other organisations, it suggested his leadership should be improved, and vice versa. Regarding well-being, he organised monthly dinners at the best restaurants, which he believed would help strengthen guanxi and knowledge exchange. It was surprising that he would host employees' parents during their visits, which he thought was enhancing guanxi and an opportunity for him to know the employee's families. He cared about employees' integrity and honesty, which could be endorsed by talking with their parents.

\section{Reflecting}

As an early career researcher, the first author engaged with constant reflections throughout the interviews, which helped to re-craft her interview skills.

Informative experience. Prior to the main periods of interviewing in both projects, the first author conducted two pilot studies, which were helpful to develop an initial sense about how to strategise the subsequent interviews. In the $\mathrm{PhD}$ project, she spent enormous time reflecting on the interviews at the end of each day. When playing back the recording, she realised that she had spent excessive time taking notes and occasionally jumped to talk before the interviewees could finish their answers. She was also aware the interviews could be better-honed in several ways, creating rapport and being more informative by having an informal chat or communication before each interview. She found herself 
frequently struggling to break the ice when meeting with interviewees, where both parties appeared strangers to each other. Chinese people tend to be suspicious of strangers such that they appear unwilling to talk without any 'catch-up' in advance. The experience in the post-doc project was different. While the $\mathrm{PhD}$ research engaged with leaders across many organisations, the in-depth case study for the post-doc project included interviewees from other departments within the same organisation. The interview guide questions for all interviewees were the same and related to identity (targeted at internal stakeholders) and reputation (targeted at external stakeholders). Reflecting on the interviews after a couple of days, the first author noticed the difference: some interviewees, such as those from the Research and Developemt and transaction departments, mainly focused on internal interaction. Thus they were engaged with answering questions related to identity. However, they were either unable or even embarrassed to answer when asked about reputation-related questions. Informed by this, the first author changed the order and focus of the interview guide questions aligning with the specific position of each interviewee in an attempt to arouse their enthusiasm to talk. Although it is well-known that interviewers should be flexible with the structure and order of their questions, this is an essential reminder of how this can foster deeper interviewee engagement and richer responses to questions.

Open to idiosyncrasy. The $\mathrm{PhD}$ project was different from the post-doc project, and no interview was the same. However, three out of the 42 interviews appeared particularly idiosyncratic. First, in the post-doc project, one of the interviewees (Interviewee 9) was a famous elite who had been frequently discussed on various social media sites. She was a particularly important figurehead in the company (Deputy General Manager). Unexpectedly, as soon as she sat down for the interview before the first author could ask her any questions, she began to talk incessantly for approximately 40 minutes. Over a brief pause, the first author managed to interpose one question, which was immediately followed by another 40-min soliloquy. Hence, the 80 -min interview became an almost exclusively one-way talking shop for the interviewee and of limited value. Another case in the postdoc project included a high power difference between two interviewees: a Board Chairman (Interviewee 1) and a director (Interviewee 17). Given the top level of the Board Chairman, as mentioned earlier, the thorough preparation did not make the first author feel confident but more anxious as she had no experience in interviewing such an 'ultra elite'. To relieve her stress, she prepared several approaches for different scenarios. For example, to cope with his potential tight schedule, she designed several options to be flexible. When she contacted him: 'what time would you be available for an interview?', to her surprise, he replied: 'any time is fine for me'. This was completely unexpected. His extreme approachability was also illustrated at the end of the interview when he walked her out of his office and kept with her until the car for her lift had arrived. While a host might walk the guest out of the office, it is rare for a host to go so far.

In sharp contrast, the first author experienced the most challenging interview with a female director who attempted to dominate and patronise the interviewer, demonstrated by her response, facial expression and body language. For example, once the interviewee sat down for the interview, she began by asking in a challenging tone: 
You are from [... anonymised] school? Where is it located? I have never heard about it. (Interviewee 17)

In response to 'how does the CEO strengthen the organisational identity?', the interviewee notably raised her jaw and answered in an arrogant gesture:

The CEO has to go the extra mile to invite talented staff like me to join the company, even though I resigned and felt reluctant to return. (Interviewee 17)

The first author found herself in a situation of being patronised, so she had to project her strong guanxi with the CEO:

Oh, really? I am inquisitive about the details. I have good guanxi with the CEO, so I should talk more about it later this afternoon. (Interviewer)

Although risky, this technique was useful as the interviewee was surprised to know the guanxi between the first author and the CEO. After this exchange, she became somewhat humbler so that the interview could proceed more smoothly. In short, it is hard always to predict the idiosyncrasy of each interview based on pre-interview preparation.

Dynamic guanxi. Although guanxi is essential to gain access at the initial stage, guanxi quality is subject to change throughout interviewing, such as through engaging in a taster talk and embracing the tea culture, as discussed earlier. The dynamics of guanxi quality was particularly salient in the post-doc project. As it examined identity and reputation, we needed interviews with external stakeholders. Thanks to the strong guanxi, the CEO was highly supportive around interviewing his staff. However, despite several rounds of negotiations, he still firmly rejected us interviewing his external stakeholders such as customers:

Customers are our investors - our God. Too sensitive to be interviewed. And they are like giant monsters such as Bank of China. It is very hard or impossible to interview them. (Interviewee 5)

One incident, however, led to a change in his approach. During the 3-week fieldwork, the first author scheduled intensive interviews starting from 9:30 until 17:00. At the end of each day, the CEO frequently invited her for an informal chat. The intensity of the interviews created some problems in her throat. Once when she talked with the CEO, she could not help coughing for a few seconds. He instantly bracketed this transient moment: he looked at her sympathetically and immediately brought a bottle of mineral water, opened it up, handed it to her and emotionally articulated: 'you wouldn't need to work so hard'. The CEO had acted as a senior government leader before. Given the strong influence of Confucian culture, Chinese government leaders tend to be hierarchical. Generally, it is rare that people with government leadership experience would open up a water bottle for a young and junior researcher. The reason was likely because the CEO 
was exceptionally diligent and regarded diligence as a virtue. As indicated by the HR director, he was the 'most hardworking CEO' she had ever known. This incident was a turning point for the project. He recognised that the first author had worked extremely hard on the project and then proactively made extra efforts to support her interviews with investors: he asked the director of customer services to encourage them to engage with the research. Without such encouragement, the project may not have successfully collected data from external stakeholders.

\section{Discussion}

Drawing on the interview experiences from 42 Chinese elite leaders in China across two research projects, we have examined the methodological challenges and strategic responses of a researcher new to interviewing such elites over the three stages of fieldwork: exploring, engaging and reflecting (see Table 2).

First, we find guanxi is a prerequisite to gain research access to Chinese elites (Cunningham and Rowley, 2008) in China at the exploring stage and vital to build up trust throughout the interviewing process. However, guanxi is not static but a dynamic concept (Tsui and Farh, 1997) as guanxi quality can be enhanced through trust (Chen and Chen, 2004). Trust is essential when conducting all forms of interviews, including elites (cf. Harvey, 2011) as it enables interviewees to open up and talk. While we agree that trust is built up over time (Ostrander, 1993), we further pinpoint that trust comprises ability-based trust and sincerity-based trust, and both are important in elite interviewing in China. Ability-based trust can be enhanced by skillfully mimicking the interviewees and using visual artefacts as improvisatory prompts. For example, as a way of sensegiving, selfpromotion demonstrates the research team's academic expertise and the prestige of the institution (Welch et al., 2002) (e.g. the first author and her PhD supervisor's expertise, and the top ranking of the institutions). Sincerity-based trust is also salient and can be cultivated by selecting the right media for connection, discursive taster talks to create rapport, mimicking the interviewees and embracing tea culture to enlist engagement. For example, the coughing incident projected the researcher's diligence and earnestness, which are often regarded as virtues in China. The CEO immediately noticed it through observatory sensemaking (Weick et al., 2005), who then proactively provided further support (interviewing external stakeholders). Still, guanxi quality is not merely a given but an ongoing relationship where impressions change.

Guanxi and trust building are relational, social and context-dependent underpinned by ongoing sensemaking and sensegiving efforts, where both the interviewer and interviewee are once sensemaker and sensegiver by asking: 'what's the story here?' (Weick et al., 2005: p.410). For example, at the exploring stage, the interviewer engaged with resourceful, purposeful and interactive senesmaking which was gauged by the interviewees' responsive and informative sensegiving and interactive sensemaking. Likewise, at the engaging stage, the interviewer proactively endeavoured to secure trust, collect quality data and potentially enhance guanxi with the interviewees. On the one hand, the interviewer employed self-promotion and self-positioning sensegiving, and purposeful and interactive sensemaking. On the other hand, the interviewee actively gauged the 
Table 2. Challenges, responses and outcomes at different stages of interviewing elites.

\begin{tabular}{|c|c|c|c|c|}
\hline \multirow{2}{*}{$\begin{array}{l}\text { Stages of } \\
\text { Fieldwork }\end{array}$} & \multirow[b]{2}{*}{ Challenges } & \multicolumn{2}{|l|}{ Responses } & \multirow[b]{2}{*}{ Outcomes } \\
\hline & & Interviewer & Interviewee & \\
\hline \multirow[t]{3}{*}{ Exploring } & Guanxi matters & Sensemaking & Sensegiving & Gaining access \\
\hline & $\begin{array}{l}\text { Selecting the right } \\
\text { media }\end{array}$ & Sensemaking & Sensegiving & $\begin{array}{l}\text { Gaining access; enhancing } \\
\text { guanxi quality }\end{array}$ \\
\hline & Taster talk & Sensemaking & Sensemaking & $\begin{array}{l}\text { Enhancing guanxi quality; } \\
\text { co-positionality }\end{array}$ \\
\hline \multirow[t]{3}{*}{ Engaging } & Mimicking & Sensegiving & Sensemaking & $\begin{array}{c}\text { Enhancing guanxi quality; } \\
\text { co-positionality }\end{array}$ \\
\hline & $\begin{array}{l}\text { Using visual artefacts } \\
\text { as prompts }\end{array}$ & Sensemaking & Sensegiving & Collecting rich data \\
\hline & Embracing tea culture & Sensemaking & Sensemaking & $\begin{array}{c}\text { Enhancing guanxi quality; } \\
\text { co-positionality }\end{array}$ \\
\hline \multirow[t]{2}{*}{ Reflecting } & $\begin{array}{l}\text { Informative } \\
\text { experience }\end{array}$ & Sensemaking & Sensemaking & $\begin{array}{l}\text { Sense-becoming; co- } \\
\text { positionality }\end{array}$ \\
\hline & $\begin{array}{l}\text { Open to idiosyncrasy } \\
\text { Dynamic guanxi }\end{array}$ & $\begin{array}{l}\text { Sensemaking } \\
\text { Sensegiving }\end{array}$ & $\begin{array}{l}\text { Sensegiving } \\
\text { Sensemaking }\end{array}$ & \\
\hline
\end{tabular}

interviewer's positionality, ability and sincerity through observatory and interactive sensemaking as well as informative sensegiving. For example, the first author switched to varied sensegiving strategies by mimicking the interviewees: she purposefully purported to be a 'countryside girl' in the $\mathrm{PhD}$ project (a peripheral industry), and deliberately hinged on self-promotion by highlighting the knowledge of her research team in the postdoc project (an elite firm and industry). As another example, the first author used visual representations as sensegiving prompts (Kosslyn et al., 1995) to engage the interviewees (purposeful sensemaking). While the relation between sensemaking and materiality has been forged (Garreau et al., 2015), our study shows artefacts can 'play a functional and symbolic role' (Hawkins, 2015: p.953) to disseminate sensegiving in elite interviewing, as Chinese people tend to be attached to aesthetic representations, particularly to colours and pictures (Nie et al., 2009).

The last stage is reflecting, consisting of the interviewer's retrospective sensemaking and proactive sensegiving and the interviewee's reactive sensegiving. For example, in the case of interviewing the ultra elite (Zuckerman, 1972) (the Board Chairman), having experience of elite interviewing before such an important interview is valuable in terms of confidence and acquiring particular approaches for interviewing. However, it is also essential to keep openness to embrace idiosyncrasies and unforeseen dynamics. By reflecting on the interviewing process, the interviewer evolved a better sense of strategising the ensuing interviews, a process we term sense-becoming. The interviewee also reflected on whether to provide further support and recommend other contacts to the interviewer.

The three stages of fieldwork indicate that research represents a shared space co-shaped by the interviewer and interviewee (England, 1994): they may have 'multiple overlapping 
identities' and 'make meaning from various aspects of their identity' (Kezar, 2002:96), and the identities of both parties can reciprocally impact each other (Bourke, 2014). Rather than being solely dominated by a single party through a marked bifurcation of insider/outsider, elite interviewing invites both parties to keep inherent openness to embrace what is going on (Sutcliffe, 2000). It echoes the role of Aristotelian phronesis, which 'as an intellectual virtue takes a combination of experience, deliberation, intuition and an adequate choice of means in a given situation' (Thuesen, 2011:614). A proliferation of work (Harvey, 2011; Zuckerman, 1972) emphasises the benefit of thorough preinterview preparation and suggests it can enhance positionality of the interviewer by heightened-levels of self-presentation (McDowell, 1998) and self-promotion (Okumus et al., 2007), which emphasises dualisms, but fails to take the social context into full play. We find positionality is dynamic and evolving throughout research, and reciprocally influencing both parties (Mikecz, 2012): a process that we refer to as 'co-positionality'. Drawing on the inter-related sensemaking and sensegiving efforts, researchers new to interviewing elites can craft and re-craft a sense about how to strategise the subsequent interviews, which is a process we term 'sense-becoming'.

This article demonstrates guanxi, sensemaking, and positionality are essential for researchers conducting elite interviews, which remain under-explored. Guanxi is central to elite interviewing within Chinese contexts, and guanxi quality is dynamic and can be enhanced by multiple ways such as employing social media (i.e. WeChat), taster talks and visual representations. It is crucial for interviewers and interviewees to proactively engage with the ongoing sensemaking and sensegiving processes through 'co-positionality'. The researcher can gradually evolve a sense of performing better, leading to everyday 'sensebecoming'. Figure 1 provides a heuristic for conceptualising the salience of guanxi and sensemaking for elite interviews in China. Quadrant 1 (Q1), for example, shows that when there is low sensemaking and low guanxi, the outcome can be quite domineering from the interviewee who may patronise or respond to questions by soliloquy. Quadrant 2 (Q2) is when sensemaking is high but guanxi is low, leading to specific approaches to build rapport between the interviewer and interviewee (e.g. taster talk or embracing the tea culture). Quadrant 3 (Q3) is when sensemaking is low, and guanxi is high, and there may be a good rapport between the interviewer and interviewee, but the latter struggles to engage fully with the interviewee through verbal and non-verbal prompts and cues. Quadrant 4 (Q4) is when there is both high sensemaking and guanxi, which helps to foster both sense-becoming and co-positionality.

\section{Conclusions}

We provide three contributions to the literature on elite interviews, drawing on our experience of conducting fieldwork in China. First, responding to the importance of guanxi (cf. Farh et al., 1998; Jacobs, 1980), we highlight guanxi is central to elite interviewing through securing access and trust with Chinese elite leaders. Consistent with the significance of trust in elite interviewing, we argue that trust can be enhanced by guanxi quality comprising ability-based trust and sincerity-based trust. Second, responding to the call of seeing research as 'a process' (England, 1994), we find guanxi is 


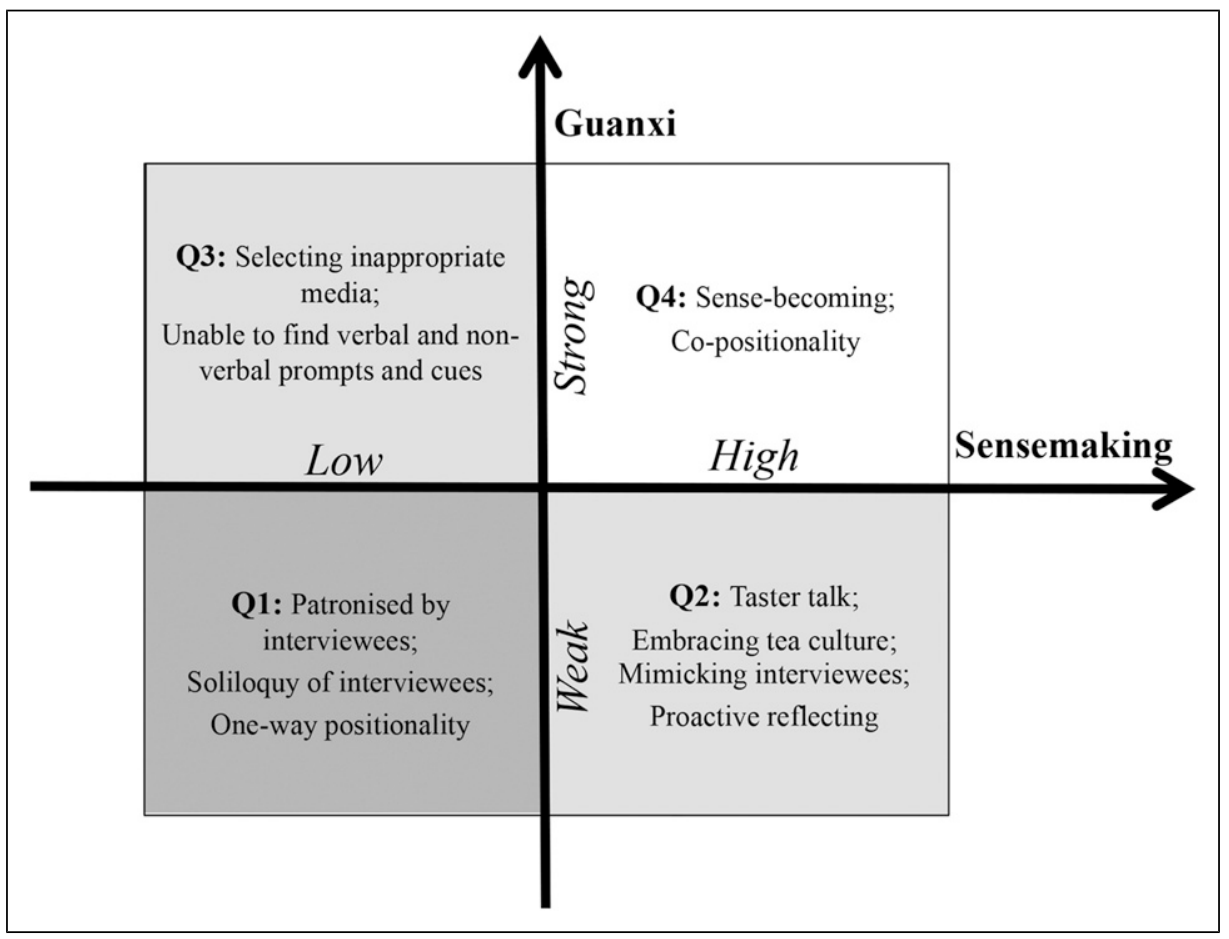

Figure I. A heuristic for conceptualising the salience of guanxi and sensemaking for elite interviews in China.

embedded in this relational and dynamic process, combining the sensemaking and sensegiving efforts of the interviewer and interviewee. By reflecting on the ongoing process, researchers can develop a sense of strategy for future interviews, which we refer to when introducing the concept of 'sense-becoming'. Third, the interviewer and interviewee are reciprocally the sensemaker and sensegiver through the co-authorship of guanxi during interviews, a process we term 'co-positionality'.

This article provides theoretical and practical insights into conducting elite interviews with Chinese leaders in the context of China. We find guanxi is central to Chinese elite interviewing, which is a relational and dynamic process constitutive of sensemaking and sensegiving efforts co-authored by the interviewer and the interviewee, although the former slants at sensemaking and the latter at sensegiving. We have also sought to provide a wider cultural and geographic lens compared to existing methodological approaches to the sociology of work. Building on McDowell (1998), one cultural aspect that we observed some subtle dynamics was the aspect of gender. For instance, the first author as a young female observed support from many male interviewees, but some challenges and difficulties with female interviewees. Although this was not the focus of this paper, we suggest that gender and other social characteristics warrant further research in conducting elite interviews in China. 


\section{Declaration of conflicting interests}

The author(s) declared no potential conflicts of interest with respect to the research, authorship, and/ or publication of this article.

\section{Funding}

The author(s) received no financial support for the research, authorship, and/or publication of this article.

\section{ORCID iD}

William S Harvey (D) https://orcid.org/0000-0002-8771-4000

\section{References}

Alvesson M (2003) Beyond neopositivists, romantics, and localists: a reflexive approach to interviews in organizational research. Academy of Management Review 28: 13-33.

Bourke B (2014) Positionality: reflecting on the research process. The Qualitative Report 19: 1-9. Case P and Gosling J (2007) Wisdom of the moment: pre-modern perspectives on organizational action. Social Epistemology 21: 87-111.

Chen X-P and Chen CC (2004) On the intricacies of the Chinese guanxi: a process model of guanxi development. Asia Pacific Journal of Management 21: 305-324.

Cooke FL (2002) Ownership change and reshaping of employment relations in China: a study of two manufacturing companies. Journal of Industrial Relations 44: 19-39.

Cunningham LX and Rowley C (2008) The development of Chinese small and medium enterprises and human resource management: a review. Asia Pacific Journal of Human Resources 46: 353-379.

Dunfee TW and Warren DE (2001) Is guanxi ethical? A normative analysis of doing business in China. Journal of Business Ethics 32(3): 191-204.

Elsbach KD, Barr PS and Hargadon AB (2005) Identifying situated cognition in organizations. Organization Science 16: 422-433.

Empson L (2017) Elite interviewing in professional organizations. Journal of Professions and Organization 5: 58-69.

England KVL (1994) Getting personal: reflexivity, positionality, and feminist research. The Professional Geographer 46: 80-89.

Farh J-L, Tsui AS, Xin K, et al. (1998) 'The influence of relational demography and guanxi: The Chinese case'. Organization Science 9: 471-488.

Garreau L, Mouricou P and Grimand A (2015) Drawing on the map: an exploration of strategic sensemaking/giving practices using visual representations. British Journal of Management 26: 689-712.

Gioia DA and Chittipeddi K (1991) Sensemaking and sensegiving in strategic change initiation. Strategic Management Journal 12: 433-448.

Haas MR (2006) Knowledge Gathering, Team Capabilities, and Project Performance in Challenging Work Environments. Management Science 52: 1170-1184.

Harvey (2011). [Details witheld for peer review]. 
Harvey (2021). [Details witheld for peer review].

Hawkins B (2015) Ship-shape: materializing leadership in the British royal navy. Human Relations 68: 951-971.

Heneman RL, Tansky JW and Camp SM (2000) Human resource management practices in small and medium-sized enterprises: unanswered questions and future research perspectives. Entrepreneurship Theory and Practice 25(1): 11-26.

Hofstede G (2011) Dimensionalizing cultures: the hofstede model in context. Online Readings in Psychology and Culture 2(1): 8.

Jacob SA and Furgerson SP (2012) Writing interview protocols and conducting interviews: tips for students new to the field of qualitative research. The Qualitative Report 17: 1-10.

Jacobs JB (1980) The concept of guanxi and local politics in a rural Chinese cultural setting. In: Greenblatt SL, Wilson RW and Wilson AA (eds), Social Interaction in Chinese Society. New York: Praeger, pp. 209-236.

Kezar A (2002) Reconstructing static images of leadership: an application of positionality theory. Journal of Lesbian Studies 8: 94-109.

Kezar A (2003) 'Transformational elite interviews: principles and problems'. Qualitative inquiry 9: 395-415.

Kosslyn SM, Thompson WL, Klm IJ, et al. (1995) Topographical representations of mental images in primary visual cortex. Nature 378: 496-498.

Lee B and Aslam U (2018) Towards the wholesome interview: technical, social and political dimensions. In: Cassell C, Cunliffe A and Grandy G (eds), The SAGE Handbook of Qualitative Business and Management Research Methods: Methods and Challenges. London: Sage Publications, pp. 102-116.

Lu LT (2012) Guanxi and renqing: the roles of two cultural norms in Chinese business. International Journal of Management 29(2): 466.

Madge C (1993) Boundary disputes: comments on sidaway (1992). Area 25: 294-299.

Maitlis S and Christianson M (2014) Sensemaking in organizations: taking stock and moving forward. Academy of Management Annals 8: 57-125.

Mavin S, Grandy G and Williams J (2014) Experiences of women elite leaders doing gender: intragender micro-violence between women. British Journal of Management 25: 439-455.

McAllister DJ (1995) Affect- and cognition-based trust as foundations for interpersonal cooperation in organizations. Academy of Management Journal 38: 24-59.

McDowell L (1998) Elites in the City of London: some methodological considerations. Environment and Planning A: Economy and Space 30: 2133-2146.

Mikecz R (2012) Interviewing elites. Qualitative Inquiry 18: 482-493.

Nie W, Xin K and Zhang L (2009) Made in China: Secrets of China's Dynamic Entrepreneurs. Hoboken NJ: Wiley.

Okumus F, Altinay L and Roper A (2007) Gaining access for research. Annals of Tourism Research 34(1): 7-26.

Ostrander SA (1993) "Surely you're not in this just to be helpful". Journal of Contemporary Ethnography 22: 7-27.

Pye A (2005) Leadership and organizing: sensemaking in action. Leadership 1: 31-49.

Smigel EO (1958) Interviewing a legal elite: the wall street lawyer. American Journal of Sociology 64(2): 159-164. 
Sonenshein S (2010) We're changing-or are we? Untangling the role of progressive, regressive, and stability narratives during strategic change implementation. Academy of Management Journal 53: 477-512.

Starbuck WH and Milliken FJ (1988) Executives' perceptual filters: what they notice and how they make sense. In: Hambrick DC (ed), The executive effect: Concepts and methods for studying top managers. Greenwich, CT: JAI Press, pp. 35-65.

Sutcliffe KM (2000) Organizational environments and organizational information processing. In: Jablin FM and Putnam LL (eds), The New Handbook of Organizational Communication. London: Sage, pp. 197-230.

Thuesen F (2011) Navigating between dialogue and confrontation: phronesis and emotions in interviewing elites on ethnic discrimination. Qualitative Inquiry 17: 613-622.

Tsui AS and Farh J-LL (1997) Where guanxi matters. Work and Occupations 24: 56-79.

Weick KE (1995) Sensemaking in Organizations. London: Sage.

Weick KE, Sutcliffe KM and Obstfeld D (2005) Organizing and the Process of Sensemaking. Organization Science 16: 409-421.

Welch C, Marschan-Piekkari R, Penttinen H, et al. (2002) Corporate elites as informants in qualitative international business research. International Business Review 11: 611-628.

Yang CF (2001) Acritical reviewof the conceptualization of guanxi and renqing. In: Yang CF (ed), The Interpersonal Relationship, Affection, and Trust of the Chinese:Froman InteractionalPerspective. Taipei: Yuan Liou Pulishing Co, pp. 3-26. (in Chinese).

Zuckerman H (1972) Interviewing an ultra-elite. Public Opinion Quarterly 36: 159-175. 